\title{
COMPREENSÓES DE ALUNAS DO ENSINO FUNDAMENTAL SOBRE O ENSINO DO FUTEBOL NA ESCOLA E NA ESCOLINHA DE FUTEBOL
}

\author{
Derli Juliano Neuenfeldt ${ }^{1}$ \\ Franciele Lansing ${ }^{2}$
}

\begin{abstract}
Resumo: Esta pesquisa qualitativa analisou a compreensão de alunas do Ensino Fundamental sobre o ensino do futebol na escola e na escolinha de futebol. Coletaram-se informações através de uma entrevista realizada com oito alunas do $60^{\circ}$ ao $9 .^{\circ}$ Ano e com as duas professoras de Educaçáo Física. Constatou-se que na escola o futebol é ensinado sem ênfase na especialização do esporte, ao contrário da escolinha. $\mathrm{Na}$ escola ensina-se de forma diversificada, através de brincadeiras; na escolinha, enfatizam-se os aspectos físicos e táticos. A participação das alunas em campeonatos é mais frequente ao representarem a escola. Conclui-se que as alunas compreendem que na escolinha há maior aprofundamento no ensino do futebol, sendo a escolha da prática desse esporte influenciada pela escola e pela família.
\end{abstract}

Palavras-chave: Educação Física Escolar. Futebol. Ensino. Gênero.

\section{PRIMARY SCHOOL STUDENT'S UNDERSTANDING ABOUT SOCCER TEACHING IN THE SCHOOL AND IN THE SOCCER SCHOOL}

\begin{abstract}
This qualitative research evaluated primary school student's understanding about soccer teaching in school and in soccer school. Data was collected through interviews of eight female students from 6th to 9th grade, as well as two physical education teachers. It was found that in the school soccer is taught in a diversified way, with play; in the soccer school, physical and tactical aspects are emphasized. Also, female student's participation in championships is more frequent when representing the school. It is concluded that female students understand that, in the soccer school, the sport is taught more in-depth, and the choice to train soccer seems to be influenced by both the school and the family.
\end{abstract}

Keywords: School Physical Education. Soccer. Teaching. Gender.

1 Doutorado em Ciências: Ambiente e Desenvolvimento. Professor do Programa de Pós Graduaçáo em Ensino da Universidade do Vale do Taquarari - Univates.

2 Licenciada em Educação Física pela Universidade do Vale do Taquari - Univates.

-- Artigo Recebido em 04/02/2020. ACeito em 08/07/2020. --

Signos, Lajeado, ano 41, n. 1, p. 204-218, 2020. ISSN 1983-0378 


\section{INTRODUÇÃO}

Você já parou para pensar que a maior artilheira da história do Brasil entre os times masculino e feminino de futebol é uma mulher? Já ouvir falar da Marta? Mas nem tudo é um mar de rosas na trajetória de participação da mulher no esporte e na sociedade.

No Brasil, em 1941, a Lei n. 3.199 de 1941 (BRASIL, 1941) proibia às mulheres a prática de desportos incompatíveis com as condições de sua natureza (BRUHNS, 2000). Em 1965, o Conselho Nacional de Desportos (CND) manteve a proibição a prática feminina de esportes, como lutas, futebol e polo aquático. Estas proibiçôes relacionam-se com a compreensão do papel social das mulheres. Mourão (2000) destaca que as mulheres eram representadas como frágeis, incapazes, um corpo que deveria ser preservado apenas para a função de reprodução. A preocupação da época era que as mulheres não poderiam gastar energia com outras atividades, pois seria necessário preservarem-se para a reprodução. Dessa forma, os esportes, principalmente aqueles com contato físico, não eram permitidos a elas.

Essa concepção predominou no Brasil, segundo Castellani Filho (1991), até a década de 1970, sendo oriunda do movimento higienista no período colonial, em meados do século XIX. Entendia-se que "[...] mulheres fortes e sadias teriam mais condiçóes de gerarem filhos saudáveis, os quais estariam mais aptos a defenderem a Pátria, no caso dos homens, e de se tornarem máes robustas, no caso de mulheres" (CASTELLANI FILHO, 1991, p. 56).

As mulheres percorreram um caminho muito longo até conseguirem reconhecimento no campo esportivo, principalmente, em se tratando do futebol, confrontando-se com barreiras culturais. Sabe-se que, atualmente, o futebol é uma modalidade esportiva praticada tanto por homens como por mulheres. Hoje, no Brasil, não existe mais nenhuma legislaçáo que proíbe a prática do futebol por mulheres; contudo, ainda há pessoas que o consideram um esporte masculino (MOURÃO, 2000). Talvez este seja o fator que cause e justifique a dificuldade das mulheres em encontrar um espaço de destaque nesta modalidade esportiva. Consequentemente, mais difícil ainda é obter apoio financeiro.

Porém, muitas barreiras foram quebradas e encontramos mulheres praticando futebol na escola, no lazer e no alto rendimento. Em se tratando de prática do futebol na escola, referimo-nos ao sentido educativo do esporte. Em se tratando de lazer, entendemos o aspecto social do futebol, cujo objetivo é a descontração, o divertimento, o bem-estar e a própria saúde. Já no que diz respeito ao rendimento, o atleta visa obter resultados satisfatórios na competiçáo, buscando superar seus limites e os do próprio adversário.

Um dos maiores equívocos do ensino do esporte na escola foi conduzi-lo na perspectiva do esporte de rendimento, tornando-se seletivo e excludente. Em se tratando do esporte com foco no rendimento, segundo Bracht (2000), as ações são julgadas pelo seu resultado final. Ou seja, a performance no esporte mensurada/ 
valorizada é em função da vitória ou da derrota; inclusive, os meios empregados no treinamento são medidos levando em consideração o resultado final.

Por outro lado, para Bracht (2000), o esporte na escola, enquanto atividade escolar, só tem sentido se for integrado ao Projeto Pedagógico da escola. Por isso, uma pedagogia crítica na Educação Física está condicionada por aquilo que realmente acontece na escola como um todo, ou seja, deve estar articulada com os objetivos escolares, o que, provavelmente, representará os avanços e as contradiçóes deste contexto.

Segundo Stigger e Lovisolo (2009), partindo do ponto de vista do papel da escola quanto ao ensino do esporte, devemos reconhecer a sua evidência social e assim considerar que a instituição escolar não pode ficar alheia ao fenômeno sociocultural. Podemos considerar que entre os espaços em que o esporte é praticado, a escola tem o papel de transmitir a prática social para as geraçôes futuras com a ajuda dos professores de Educação Física.

Dessa forma, a partir da temática, a mulher e a prática do futebol, este estudo analisa compreensóes de alunas do 6..$^{\circ}$ ao 9..$^{\circ}$ Ano do Ensino Fundamental, acerca do ensino do futebol na escola e na escolinha de futebol, identificando metodologias utilizadas pelas professoras com as alunas, tanto na escola, como na escolinha esportiva, bem como, questionando a ênfase dada aos aspectos físicos e táticos. O estudo também analisa os motivos que levaram as alunas a optarem pelo futebol na escolinha de futebol, que é um espaço não-escolar.

A partir desse estudo, espera-se contribuir para a reflexão sobre o ensino do futebol na escola e na escolinha de futebol, trazendo informações científicas da forma como o futebol é compreendido pelas alunas em cada um desses lugares. Nesse contexto, também se deseja possibilitar a análise da forma como o futebol insere-se na vida das mulheres a partir da escola e da família.

\section{METODOLOGIA}

A metodologia utilizada neste estudo foi de corte qualitativo e descritivo. Segundo Sampieri, Collado e Lucio (2013), opta-se pelo estudo qualitativo, quando se busca compreender a perspectiva dos participantes sobre os acontecimentos que estão em seu entorno e, a partir de seus pontos de vista e experiências, compreender as opinióes e significados que o sujeito atribui a eles. Mattos (2016) acrescenta que a pesquisa qualitativa é utilizada para descrever uma situação social específica, conhecida também como pesquisa descritiva.

A pesquisa foi realizada numa escola pública da rede municipal de ensino e numa escolinha de futebol, ambas da mesma cidade do Vale do Taquari/RS/BRA. Os critérios para a escolha delas foram o fato de os pesquisadores conhecerem as instituiçóes, devido a uma das professoras lecionar tanto na escola como também na escolinha esportiva e por ter alunas que praticavam futebol nos dois lugares.

O estudo foi realizado com as duas professoras de Educaçáo Física e com oito alunas do Ensino Fundamental dos Anos Finais, duas de cada Ano (6. a a 9. ${ }^{\circ}$, 
que praticam o futebol na escola, como conteúdo da Educação Física escolar, e na escolinha de futebol. A escolinha de futebol, que funciona há onze anos, conta com 35 atletas. Ao longo de sua existência, ela tem participado de campeonatos e de torneios, como, por exemplo, a Campeonato Piá ${ }^{3}$, além de jogos amistosos. A escola possui em torno de 240 alunos, com turmas do $3 .^{\circ}$ ao $9 .^{\circ}$ ano. Através da escola, as alunas participam de campeonatos como o Guri Bom de Bola e os JERGS 4 .

Em relação a coleta de informaçóes, realizou-se uma entrevista semiestruturada, que foi gravada, e, posteriormente, transcrita para o word. Todas as entrevistas foram desenvolvidas para as professores e alunas para que pudessem ler a transcrição e, a partir disso, validar e autorizar o uso das informaçôes.

Em relaçáo aos cuidados éticos, assinaram o termo de consentimento livre e esclarecido as professoras entrevistadas, bem como os pais ou responsáveis pelas alunas que eram menores de 18 anos. As alunas assinaram o termo de assentimento que torna a pesquisa clara para as entrevistadas e as deixam cientes de suas responsabilidades em relação à pesquisa. Foi também assegurado aos participantes a não identificação de informaçôes pessoais que pudessem identificá-las. Para preservar o sigilo do nome dos sujeitos, foram atribuídos códigos para alunas, tais como aluna 1, aluna 2 , aluna $3 \ldots$ até aluna 8 . O mesmo procedimento também foi adotado para as professoras, no caso, professora 1 e professora 2.

A coleta de dados teve início após a aprovação do Projeto de Pesquisa pelo Comitê de Ética e Pesquisa da Univates (COEP) ${ }^{5}$, que garante os preceitos éticos da pesquisa em seres humanos, conforme preconizado na Resolução 466/2012.

A análise de informaçóes foi organizada por categorias e por estudos comparativos. Flick (2009, p. 135) diz que "num estudo comparativo, não se observa o caso como um todo, nem em toda a sua complexidade; em vez disso, observa-se a multiplicidade de casos relacionados a determinados excertos". Isto é, podemos comparar conteúdos relativos às experiências de um grande e/ou de um pequeno número de pessoas. Definiu-se como categorias de análise: a) A escola e a família como porta de entrada das mulheres para o mundo esportivo; b) Compreensóes das alunas sobre o ensino futebol na escola e na escolinha de futebol.

$\mathrm{Na}$ análise de informações, fez-se uso da triangulaçáo, que permite ao pesquisador lançar mão de técnicas com vistas a ampliar informações em torno de

3 O evento é realizado pela Prefeitura de Lajeado, por meio da Secretaria de Cultura, Esporte e Lazer, com o objetivo de proporcionar integração entre os participantes, comunidade e familiares. Tem-se a participação de equipes de todos o RS, nos naipes masculino e feminino, constituídas de crianças e adolescentes.

4 Campeonato Guri Bom de Bola é um evento formativo e social, que não visa lucro comercial por meio deste esporte, mas oportunizar às crianças espaços para socializaçáo, descobrindo o prazer do jogo e das brincadeiras. Os JERGS são os Jogos Escolares do RS que têm por finalidade estimular a prática esportiva em todas as escolas públicas do estado (municipais, estaduais e federais), buscando a mobilizaçáo da comunidade escolar em prol do esporte educacional.

5 Projeto de Pesquisa Aprovado pelo Coep/Univates. Parecer número 2.840.872, em 23/08/2018. 
seu objeto de pesquisa, como também optar por um comportamento prático de estudo, sob diferentes perspectivas, a fim de complementar a temática pesquisada, ao mesmo tempo em que se aumenta a consistência das conclusóes (MARCONDES; BRISOLA, 2014).

\section{A ESCOLA E A FAMÍLIA COMO PORTA DE ENTRADA DAS MULHERES PARA O MUNDO ESPORTIVO}

Esta categoria se propóe, através das entrevistas com as professoras e com as alunas, compreender os motivos que levaram as alunas a optarem pela prática do futebol na escolinha esportiva. Nessa análise, apresenta-se o papel da escola, em especial, da Educação Física, e da família, como motivadores da escolha.

Para Guimarães (2004) apud Cabral e Negreiros (2014), a motivação no contexto escolar tem sido avaliada como um determinante crítico do nível e da qualidade da aprendizagem e do desempenho. Um estudante motivado mostra-se ativamente envolvido no processo de aprendizagem, não apenas desafiando seus limites em tarefas complexas, mas também buscando desenvolver novas habilidades de compreensão e de domínio.

Nesse sentido, as falas abaixo apresentam o incentivo da professora de Educaçáo Física para que as alunas jogassem futebol e buscassem praticá-lo também fora da escola:

"Eu sempre jogava só na escola o futebol, dai a professora me pediu se eu queria começar a fazer a escolinha, ai eu resolvi começar e convidei minhas amigas que começaram a jogar também" (Aluna 7).

"Eu comecei, na verdade, porque a professora iria para um campeonato pela escola e ela precisava de meninas, mas eu não jogava, jogava na escola só por jogar mesmo. Dai ela me levou junto, para ter números na verdade. A partir dai eu peguei o gosto e comecei a ir na escolinha e comecei a jogar mais" (Aluna 1).

Percebe-se nas falas acima que o incentivo da professora foi fundamental para as alunas despertarem o gosto pelo futebol, assim como para o experimentarem em um contexto diferente do escolar. Balbinotti et al. (2007) afirmam que a motivação é um fator importante para o efetivo engajamento dos alunos nas práticas esportivas. Além disso, há de destacar o papel da Educaçáo Física Escolar no respeito ao direito à prática do esporte, sem distinçôes de gênero. Segundo Vago (1996), o esporte é influenciado, condicionado ou até mesmo determinado pelo ensino da Educaçáo Física na escola. Ou seja, a Educação Física Escolar exerce influência sobre o esporte. Ela é a base da pirâmide esportiva, sendo um dos locais onde o talento dos alunos poderá ser descoberto.

O fato de haver incentivo na escola para a prática do futebol na Educação Física escolar, para alunos e alunas, faz com que, segundo a entrevista da professora 2 , as alunas gostem muito do futebol. A professora menciona que se fosse depender delas, nas aulas de Educação Física seria só o futebol: "[...] porque se tu deixas elas querem o futebol toda semana [...]". 
Ainda, quando ao incentivo para a prática do futebol na Educação Física Escolar, as alunas destacam, também, a influência dos meninos para que jogassem junto com eles:

"Eu comecei a jogar futebol por causa dos guris da nossa turma, porque nenhuma guria da nossa turma jogava" (Aluna 3).

"Na verdade, eu comecei a jogar of futebol por causa dos meninos. Eles gostavam muito e nós não gostávamos nenhum pouco. Ai eles foram chamando aos poucos a gente para jogar, e foi ai que eu comecei a gostar [...]" (Aluna 8).

A realidade encontrada na escola, quanto ao incentivo da prática do futebol para as alunas, não é o que normalmente ocorre. Todaro (1997) apud Darido (2002) fala da falta de oportunidades na escola para a prática do futebol feminino. Atletas da seleção brasileira de futebol feminino começaram a praticar futebol nas ruas, clubes e praias, porque não tiveram incentivo na escola. A autora ainda fala que isso pode ter ocorrido, porque, quanto maior o número de pessoas observando nas aulas de Educação Física, especialmente se for do sexo masculino, mais as alunas se intimidam em participar de atividades consideradas predominantemente masculinas.

Essa pesquisa contrapóe a realidade descrita pelo autor acima, pois, ao analisar as falas das alunas, elas mencionam que começaram a jogar futebol "por causa dos guris da nossa turma", pois "les foram chamando a gente para jogar". Isso contribuiu para despertar nelas o gosto pelo esporte e a terem reconhecimento junto aos meninos do potencial para a prática do futebol. Esse dado reforça a importância da escola e da Educação Física Escolar no sentido de rever preconceitos em relação à prática de esportes por alunas, rompendo como a cultura brasileira na qual predomina a compreensão de que homens e mulheres devem fazer práticas corporais distintas. Culturalmente Moura (2005) diz que isso se expressa claramente quando, na infância, os brinquedos para as meninas são bonecas e para os meninos bolas de futebol, ou seja, socialmente ainda se entende que a menina deve destinar-se a brincadeiras que remetem a vida privada, o lar, os afazeres domésticos, enquanto que aos meninos de imediato se apresenta o esporte, no caso o futebol, como primeira brincadeira.

Ainda, além do incentivo das professoras de Educação Física e colegas de escola, a família também é mediadora na escolha do futebol como prática esportiva com que hoje as alunas do estudo se identificam, como podemos ver nas falas abaixo:

"A professora da escolinha disse que quem queria começar na escolinha poderia começar, eu não gostava de futebol. Ai eu cheguei e disse para a minha irmã que jogava futebol, era goleira, dai ela disse que eu deveria começar, foi aí que eu comecei então a jogar" (Aluna 2).

"Primeiro eu e meu irmáo, nós tínhamos bolas e ele fazia goleiras de madeira, dai nós dois jogávamos e com isso comentava com a minha mãe que eu gostaria de fazer escolinha de futebol porque todas as minhas amigas já faziam. Ela falou que eu poderia e até agora continuo fazendo" (Aluna 4). 
"O futebol uma influência do meu pai, ele sempre gostou, sempre foi do esporte. Quando eu tinha 3 anos ele já me levava junto nos jogos e fui aprendendo desde pequena, sempre gostei" (Aluna 6).

Constata-se que a influência dos pais e irmãos, seja permitindo as filhas (alunas) praticar na escolinha de futebol, possibilitando jogar junto ou levandoas em ambientes onde o futebol era praticado, foi fundamental para elas compreenderem que futebol também é para mulheres. $\mathrm{O}$ apoio e o incentivo foram determinantes para motivar as alunas a praticarem o futebol também fora da escola. Em decorrência daquilo que fazem, pensam e dizem, a família e os amigos acabam contribuindo para a estruturação de um ambiente favorável à iniciação esportiva, configurando-se, muitas vezes, em um alicerce a partir do qual despontam e se desenvolvem talentos esportivos (COUTINHO, 2014).

Portanto, o incentivo das professoras nas aulas de Educaçáo Física, a prática junto com meninos e o apoio da família contribuem para que as alunas joguem futebol. Logo, a escola e a família são, nesse estudo, a porta de entrada para o mundo esportivo das alunas, neste caso, sendo determinantes para a escolha da prática do futebol fora da escola. Apesar de ser uma modalidade com uma visibilidade maior para o gênero masculino, o futebol feminino tem crescido e atraído muitas jovens que começam a praticar a modalidade dentro da escola, lutando pelo direito a essa prática esportiva.

\section{COMPREENSÓES DAS ALUNAS SOBRE O ENSINO DO FUTEBOL NA ESCOLA E NA ESCOLINHA DE FUTEBOL}

Esta categoria trata especificamente da compreensão das alunas quanto às diferenças e semelhanças do ensino do futebol na escola e na escolinha de futebol.

Sabemos que o esporte como iniciação esportiva é um dos conteúdos educativos das aulas de Educação Física e que diversas modalidades esportivas são trabalhadas na escola, como, por exemplo, futebol, voleibol, basquetebol, entre outros. Para Ramos e Neves (2008), quando falamos da iniciação esportiva, não podemos pensar somente no desenvolvimento das aulas de Educação Física, mas, sim, em todas as modalidades esportivas que são ensinadas. É um período em que a criança começa a aprender de forma mais específica a prática de um ou vários esportes.

Para compreender as diferenças que são atribuídas no âmbito escolar e da escolinha esportiva quanto à prática do futebol, as alunas foram questionadas sobre como eram as aulas em ambos os lugares. Para a aluna 2, existe mais cobrança na escolinha do que na escola: "Eu acho que a professora cobra mais na escolinha porque na escola nós fizemos mais brincadeiras". Também na escolinha, a aluna 1 traz a questão do acompanhamento individualizado e do aprofundamento: "Na escolinha a professora consegue observar as nossas maiores dificuldades, consegue nos ajudar mais para realmente a gente poder melhorar, não é que nem na escola" (Aluna 1). Já a aluna 5 diz que na escola os alunos fazem a prática por obrigação e na escolinha vai 
realmente quem gosta do futebol: "é que eu acho que na escola tem aqueles que fazem sempre por obrigação, que não tem vontade, e na escolinha só vai realmente quem gosta de futebol".

Percebe-se, através das respostas acima que as alunas percebem diferenças entre as aulas de Educação Física e o ensino do futebol na escolinha esportiva. Entre elas destaca-se uma preocupação maior na escolinha de futebol com o aprendizado do esporte em si, ou seja, dos fundamentos técnicos e táticos, expressada quando se fala de "cobrança maior", mas também orientações individualizadas às alunas.

As falas nos remetem a pensar sobre o que compete à Educação Física Escolar ensinar no que tange ao esporte. A Educação Física escolar não é lugar para o esporte de rendimento, deve contemplar a todos. Mas como ensinar? Devemos dar ênfase aos aspectos técnicos e táticos? Bracht (2000) fala que a pedagogia crítica em Educaçáa Física propõe o ensino das destrezas motoras esportivas dotadas de novos sentidos, com novos objetivos e fins a serem construídos junto com um novo sentido próprio para o próprio esporte, ao contrário do rendimento, no qual os meios empregados no treinamento, enfim tudo é medido pelo resultado final.

Por isso, contribuindo com a discussão, há de se refletir sobre as perguntas levantadas por Fensterseifer (2013): Que lugar a Educação Física escolar ocupa na sociedade? Que lugar tem a Educação Física na escola?

Fensterseifer (2013) responde: possibilidades do se movimentar que trata da capacidade de realizar movimentos em dimensóes de espaço-temporais no ambiente físico; práticas corporais sistematizadas, vinculadas a práticas no campo de lazer, ao cuidado do corpo e da saúde e às representações sociais sobre a cultura corporal do movimento que permitem refletir sobre a origem e a dinâmica de transformação de práticas sociais que se relacionam com as atividades corporais de tempo livre; o cuidado e a educação do corpo e a organização da vida coletiva. Enfim, percebese pela resposta do autor, que a Educaçáo Física escolar assume um papel mais amplo na formação dos alunos, propondo a experimentação de práticas corporais contextualizadas com o cotidiano deles.

Retomando as respostas das alunas quanto as diferenças no ensino do futebol, em relação à metodologia utilizada nas aulas de Educaçáo Física escolar, elas falaram que há maior diversificação de práticas esportivas na escola: "A gente aquece primeiro, dai depois a professora dá atividades, tipo, uma semana é vôlei, a outra é futebol, dai na próxima handebol, basquete temos também, e assim vai" (Aluna 7). "E bem diferente, na escola a gente joga bastante voleibol, handebol, futebol, em cada aula nós jogamos alguma coisa, e na escolinha é só sempre o futebol" (Aluna 3).

Sobre o propósito das aulas de Educação Física, a professora 1, afirma trabalhar mais o esporte, mas "[...] deixo eles mais é participar, porque meu objetivo é que os alunos participem das minhas aulas [...]" (Professora 1). Ou seja, na escola, entendese que é um espaço mais lúdico, as alunas jogam mais, sem tanta preocupação com a evolução das aprendizagens quanto aos domínios técnico e tático do esporte e vivenciam diferentes esportes, não apena o futebol. 
Isso nos remete a pensarmos novamente sobre como conduzirmos o ensino do esporte na escola. Vago (1996) apresenta duas formas de ensinar o esporte no contexto escolar: o esporte na escola, que é a reprodução do esporte de rendimento, nos mesmo moldes que ocorre fora da escola; e o esporte da escola, que se apresenta como o resultado de um processo de escolarização dessa prática, permitindo adequaçóes aos objetivos da escola. Ao contrastar as palavras do autor e da professora, verificase que não há reprodução do esporte de rendimento, porém, a fala da professora nos remete a algo diferente, sendo o objetivo dela a participação das alunas, que elas gostem da prática esportiva. Há de se pensar que ensinar técnicas e táticas do esporte não o torna um esporte de rendimento, a Educaçáo Física Escolar não pode deixar de ensinar o que culturalmente se evolui, mas, sempre, tomando o cuidado para não fazer do esporte uma prática excludente, seletiva, como ocorre no esporte de rendimento.

Ainda, quanto às aulas de Educação Física na escola, as alunas reforçam o caráter lúdico ao comentarem que a professora: "Ela traz vôlei, caçador, piquebandeira, bastante coisas" (Aluna 4). "Aqui na escola nós começamos com um aquecimento, corremos um pouco, a gente brinca um pouco, só que assim, toda aula a gente faz alguma coisa diferente [...]" (Aluna 8). Quando foi falado sobre "brincar um pouco", a aluna 8 foi questionada sobre o que era esse "brincar", a que ela se referia, entendendo-se que eram atividades recreativas. "Correr, brincar de caçador, ameba" (Aluna 8).

A mesma resposta obteve-se de uma das professoras, que, antes da realização da prática de alguma modalidade, gostava de fazer um aquecimento: "É feito um alongamento, aquecimento, passo as regras mais básicas e ai depois a gente faz o jogo [...]" (Professora 2). Na sequência, perguntou-se o que era desenvolvido como aquecimento com os alunos e ela respondeu que eram brincadeiras "[...] pega-pega normal, pega-pega nas linhas, caçador gigante [...]" (Professora 2).

As atividades recreativas podem contribuir muito além do entretenimento. Silva e Sampaio (2012) argumentam que as atividades recreativas favorecem a formação autônoma dos alunos se forem realizadas com a intenção de exigir atitudes de liderança, resolução de conflitos, discussôes e construçóes coletivas, entre outros, principalmente, quando o educador as utiliza como estratégias de ensino para a resolução de problemas, partindo de ações simples relacionadas à manifestação da Cultura Corporal do Movimento, como descentralizar as decisóes sobre as açóes corporais e suas regras, mas sem abandono de sua condição de professor.

Em relação ao papel da Educação Física na escola, cabe comentar sobre a Base Nacional Comum Curricular ${ }^{6}$ (BRASIL, 2018). Ela prevê seis unidades temáticas

6 "A Base Nacional Comum Curricular (BNCC) é um documento de caráter normativo que define o conjunto orgânico e progressivo de aprendizagens essenciais que todos os alunos devem desenvolver ao longo das etapas e modalidades da Educação Básica, de modo a que tenham assegurados seus direitos de aprendizagem e desenvolvimento, em conformidade com o que preceitua o Plano Nacional de Educação (PNE) (BRASIL, 2018, p. 07). 
norteadoras das aprendizagens: brincadeiras e jogos, esportes, ginásticas, danças, lutas, e práticas corporais de aventura. É importante destacar que o caráter lúdico deve perpassar todas as práticas corporais pois ao brincar, dançar, jogar, praticar esportes os alunos se apropriam também de regras, códigos, organização, táticas, etc, assim como trocam entre si e com a sociedade, representaçóes e significados que lhes são atribuídos.

González e Fraga (2012) acrescentam que a Educação Física deve possibilitar a releitura e a apropriação dos conhecimentos da cultura corporal, pois os conhecimentos que são transmitidos na escola não estão subordinados àqueles que lidam com práticas corporais sistematizadas, como escolinhas de futsal, rodas de capoeira, entre outros. "A Educação Física, logicamente, não precisa desconhecer o que lá ocorre, porém deve ter bem claro que as finalidades naquela esfera são muito diferentes das que acontecem no interior da escola" (GONZÁLEZ; FRAGA, 2012, p.46).

Já quanto à metodologia de ensino utilizada pela professora na escolinha de futebol, as alunas compreendem que: "Ela primeiro faz um alongamento, alguns trabalhos de toque, passe e dominio, dai ela conversa, pergunta se temos dúvidas, as nossas dificuldades e depois a gente faz um jogo" (Aluna 1); "Ela vai falando sempre, se eu erro ela fala, e um pouco antes da bola chegar ela fala para ir para frente, para trás" (Aluna 2).

Assim, constata-se que as alunas praticam o futebol através de exercícios específicos que dão ênfase aos aspectos físicos e táticos. A professora se faz presente "conversando", "vendo as dúvidas", cobrando bastante os objetivos dos treinos, ou seja, atenta ao trabalho proposto, conforme falas a seguir:

"Ela cobra, por exemplo, o domínio, o passe, essas coisas, ela cobra bastante" (Aluna 1); "no meio do jogo a professora chama, ela cobra e ajuda" (Aluna 5); "ela cobra de tudo um pouco, por exemplo antes do treino da escolinha, ela faz as gurias correrem [...] ela cobra bastante o fisico" (Aluna 6).

Constata-se que as alunas, na escolinha, os treinos não se resumem ao jogo em si do futebol. Além de jogar elas praticam outros exercícios que melhoram ainda mais os fundamentos, os aspectos físicos e táticos de jogo, como, por exemplo: passe, domínio, chute a gol, entre outros, visando resultados positivos em competiçóes que costumam participar pela escola e pela escolinha. Nessa perspectiva percebese que o foco do ensino do futebol na escolinha está no rendimento esportivo, no desempenho físico e no domínio do esporte, condiçóes necessárias para participação em competiçóes.

Scaglia (1996) nos apresenta uma outra perspectiva possível. Podemos pensar numa escolinha de esportes com uma concepção de educação permanente, que tem por finalidade a responsabilidade de possibilitar um desenvolvimento ao aluno, em que o esporte não se restringe a um "fazer" mecânico, visando um rendimento exterior ao indivíduo, mas torná-lo um compreender, um incorporar, um aprender atitudes, habilidades e conhecimentos, que o levem a dominar os valores e padróes da cultura esportiva. 
Visando compreender também a questão da participação das alunas em campeonatos, todas relataram já ter participado de algum, sendo esta uma semelhança citada pelas alunas em relação à escola e à escolinha de futebol. Em relação à participação em campeonatos a aluna 3 respondeu que participou de três e de amistosos: "JERGS, Bom de Bola, Copa Piá e amistosos, são esses" (Aluna 3). Durante a conversa com uma das professoras, ela esclareceu quais os campeonatos de que participavam pela escola: "a competição da escola é o Bom de Bola e os JERGS, o Bom de Bola é futebol de campo e o JERGS é futsal" (Professora 1), dando a entender que pela escolinha participam apenas da Copa Piá.

Já a aluna 5, que já participou de dois campeonatos pela escola, conta que acabaram não sendo campeãs: "Em um deles chegamos na semifinal e no outro na final, ai nós perdemos as duas vezes nos pênaltis" (Aluna 5). Ela também participou em dois campeonatos pela escolinha de futebol e conta que ficaram uma vez em segundo lugar e na outra vez em quarto lugar: "Ficamos em 4 lo lugar, [...] ficamos em $2^{\circ}$ lugar [...]" (Aluna 5).

Dessa forma, através das falas das alunas, foi possível compreender que a participação delas em campeonatos é mais frequente pela escola do que pela escolinha de futebol. Contudo, as professoras, durante suas aulas de Educação Física, não trabalham apenas o futebol, mas, sim, diversos conteúdos. Nesta diversidade de conteúdos que são trabalhados, os aspectos físicos, táticos, não são exigidos das alunas na escola, diferentemente da escolinha de futebol. É assim que a aluna 1 compreende o ensino do futebol na escolinha: "Lá, nós estamos indo porque nós queremos, nós vamos jogar campeonatos, lá ela cobra mais" (Aluna 1), já sua compreensão quanto a escola é a seguinte: "aqui na escola já nem tanto, porque a gente tem colegas que, digamos assim, como posso te explicar, tem umas dificuldades especiais, coisas que as vezes a gente precisa ajudar esses colegas [...]" (Aluna 1).

A aluna 1 fala que participa da escolinha porque quer participar de campeonatos, mas o que chama a atenção é que a participação das alunas em campeonatos é maior na escola do que na escolinha. Entáo, qual está sendo o papel da escola quanto ao ensino e a participaçáo do futebol em campeonatos?

Vago (1996) afirma e defende a escola como um lugar de produção de cultura, ou seja, ao tratar do esporte, é possível produzir outras possibilidades de se apropriar dele. Trata-se do processo de escolarização do esporte, para fazer com que a sociedade conheça e possa usufruir de outras possibilidades de se apropriar do esporte. Esta é a apropriação das alunas: o futebol no contexto escolar é produzido dentro de outras possibilidades, mas usufruem dele também na escolinha.

Para Vago (1996) não se trata de agir apenas para que a escola tenha o seu esporte, mas, sim, de problematizar a prática cultural do esporte da sociedade, que, em outras palavras, seria o esporte da e na escola, para assim reinventá-lo, recriá-lo, reconstruí-lo, sendo entáo o papel da escola debater o esporte, criticá-lo e praticá-lo. Mas, acima de tudo, rever os códigos e valores agregados ao esporte pela forma capitalista de organização social, para construirmos outros valores a partir da 
escola, como, por exemplo, a participação, o respeito à diferença, o lúdico, sendo fundamental que seja feito para a sociedade.

Assim, além do papel da escola que é ensinar, a tarefa educacional exige preparar para algo a mais do que as atividades em específico da escola, como os jogos escolares (SAWITZKI, 2008), ou seja,

[...] contribuem para a cidadania, saúde, participação, respeito às regras, etc, além do interesse de colocar as escolas em disputa numa competiçáo para obter algum tipo de êxito sobre as outras; por outro lado, o alunado quer disputar os jogos com o intuito de ganhar, de ser campeóes, de serem melhores que as outras escolas [...] (FRIZZO, 2013, p. 168).

Logo, as possibilidades das alunas de fazer o que elas gostariam, que é participar de campeonatos, acontece, principalmente na escola. De uma forma ou outra, a escola está influenciando as alunas a buscarem na escolinha esportiva uma possibilidade de ampliação das aprendizagens relacionadas ao contexto do esporte de rendimento. Essa escolha é feita pelas alunas, de forma consciente quanto as aprendizagens e cobranças que terão na escolinha de futebol.

\section{CONSIDERAÇÓES FINAIS}

Em relação aos motivos das alunas pela escolha da prática do futebol na escolinha esportiva, evidenciou-se que a porta de entrada para o mundo esportivo é a motivação por parte das professoras de Educação Física, o convite dos meninos para jogar com eles nas aulas de Educaçáo Física na escola, assim como o apoio da família (pais e irmãos).

Das respostas obtidas sobre as compreensões das alunas quanto ao futebol na escola e na escolinha de futebol, evidenciou-se que o futebol é oferecido nas aulas de Educação Física pelas professoras da mesma forma que os demais conteúdos, sendo realizadas diversas atividades, desde aulas recreativas até regras básicas, diferentemente da escolinha, que trabalha somente o futebol. $\mathrm{Na}$ escolinha de futebol as alunas vão porque desejam evoluir no esporte nos aspectos físicos, táticos e técnicos, além do desejo de participar de competiçóes. $\mathrm{Na}$ escola, compreendem a prática do futebol associada à ludicidade e a vivência do jogo prevalece.

Apesar de a escolinha de futebol preparar as alunas para o esporte de rendimento, elas participam mais em competiçóes esportivas pela escola do que em competições pela escolinha, o que evidencia a relevância da escola na aproximaçáo das mulheres ao futebol competitivo. Contudo, a escola não pode esquecer que o esporte escolar tem cunho educativo, ou seja, deve ser meio para a formaçâo da cidadania, problematizando as competiçóes esportivas quando essas se aproximam do modelo do esporte de rendimento.

A Educaçáo Física é importante para o desenvolvimento social do aluno, educando para o lazer e para a saúde, estimulando a prática de esportes e experiências corporais diversificadas. Ela é um componente curricular importante na formação de pessoas que compreendam e respeitem as diferenças de gênero, de habilidade 
motora, étnicas e religiosas. Assim, tomando como exemplo uma constatação da pesquisa, alunas praticando na escola futebol em conjunto com os meninos, a escola diz que o futebol é para todos.

Este estudo possibilita pensarmos em novas pesquisas, tais como investigar as dificuldades enfrentadas e se ainda há preconceito em relação a atletas profissionais ou amadoras no futebol feminino. Outro tema interessante de ser investigado diz respeito a participação das mulheres na gestão do esporte. Esse ainda é um espaço que predomina a presença dos homens?

Tais estudos podem contribuir na compreensão da realidade do futebol feminino em escolas, escolinhas esportivas e clubes esportivos, assim como, para que políticas públicas possam ser definidas, atentas ao esporte como direito de todos, seja no âmbito da educação, do rendimento ou do lazer.

\section{REFERÊNCIAS}

BALBINOTTI, Carlos Adelar Abaide; BARBOSA, Marcus Levi Lopes; JUCHEM, Luciano; BALBINOTTI, Marcos Alencar Abaide; SALDANHA, Ricardo Pedrozo. A motivação à prática de atividade física regular relacionada ao prazer em adolescentes do sexo masculino. Coleçáo Pesquisa em Educaçáo Física, v. 6, n. 2, p. 13 - 18, set. 2007. Disponível em: <http://www.fontouraeditora.com.br/periodico/?mod=Arquivo\&opt=Arq uivo-Detalhe\&id_arquivo=149>. Acesso em: 31 out. 2018.

BRACHT, Valter. Esporte na escola e esporte de rendimento. Revista Movimento, Porto Alegre, v. 6, n. 12, p. XIV- XIV, out. 2000. Disponível em: <http://www.seer.ufrgs.br/ Movimento/article/viewFile/2504/1148>. Acesso em: 11 nov. 2018.

BRASIL. Decreto-lei no 3.199, de 14 de abril de 1941. Estabelece as bases de organização dos desportos em todo o país. Disponível em: <http://www.planalto.gov.br/ ccivil_03/Decreto-Lei/1937-1946/Del3199.htm>. Acesso em: 02 de jul. 2020.

BRASIL. Base Nacional Comum Curricular: Educação é a Base. Brasília, DF: Ministério da Educação, 2018. Disponível em: <http://basenacionalcomum.mec.gov.br/>. Acesso em: 08 out. 2018.

BRUHNS, Heloisa Turini. Futebol, carnaval e capoeira: entre as gingas do corpo brasileiro. Campinas: Papirus, 2000.

CABRAL, Gabriela de Medeiros; NEGREIROS, Albano Araújo. Fatores motivacionais na prática esportiva. JICE - Jornada De Iniciaçáo Científica e Extensáo. Disponível em: $<$ http://propi.ifto.edu.br/ocs/index.php/jice/5jice/paper/view/6452>. Acesso em: 15 nov. 2018.

CASTELLANI FILHO, Lino. Educaçáo Física no Brasil: A História que não se conta. 3 ed. Campinas, São Paulo: Papirus. 1991. 
COUTINHO, Patrícia Alexandra dos Santos. O percurso para a excelência no desporto: Estudo retrospectivo de fatores de treino e psicossociais em voleibolistas portugueses. Tese (Doutorado em Ciências do Desporto) - Faculdade de Desporto da Universidade do Porto, Portugal, 2014. Disponível em: <https://repositorio-aberto.up.pt/ bitstream/10216/75537/2/31284.pdf>. Acesso em: 15 nov. 2018.

DARIDO, Suraya Cristina. Futebol Feminino no Brasil: do Seu Início à Prática Pedagógica. Motriz, v. 8, n. 2, 2002. Disponível em: <http://cev.org.br/biblioteca/futebolfeminino-brasil-seu-inicio-pratica-pedagogica/>. Acesso em: 10 nov.2018.

FLICK, Uwe. Introduçáa à pesquisa qualitativa. 3. ed. Porto Alegre: Artmed, 2009.

FENSTERSEIFER, Paulo Evaldo. O que ensinar e aprender nas aulas de Educação Física. Anais do II Congresso Estadual de Educação Física na Escola: "Educcação Física Escolar: desafios à prática pedagógica". Disponível em: <https://www.univates.br/editoraunivates/publicacao/47>. Acesso em: 12 nov. 2018.

FRIZZO, Giovanni. Os jogos escolares como mecanismo de manutenção e eliminação: uma crítica à lógica esportiva na escola. Revista Movimento, Porto Alegre, v. 19, n. 04, p. 163-180, out/dez. 2013. Disponível em: <http://www.redalyc.org/ html/1153/115328881008/>. Acesso em: 10 nov. 2018.

GONZALEZ, Fernando Jaime; FRAGA, Alex Branco. Afazeres da educaçáo física na escola: planejar, ensinar, partilhar. Erechim: Edelbra, 2012

MARCONDES, Nilsen Aparecida Vieira; BRISOLA, Elisa Maria Andrade. Análise por triangulação de métodos: um referencial para pesquisas qualitativas. Revista Univap, São José dos Campos - SP, v. 20, n. 35, jul. 2014. Disponível em: <https://revista.univap.br/ index.php/revistaunivap/article/viewFile/228/210>. Acesso em 14 nov. 2018.

MATTOS, Rafael da Silva. Pesquisa qualitativa em educaçáo física: da graduaçáo ao doutorado. Curitiba: CRV, 2016.

MOURA, Eriberto Lessa. O futebol como área reservada masculina. In: DAOLIO, Jocimar (Orgs). Futebol, cultura e sociedade. Campinas: Autores Associados, 2005.

MOURÃO, Ludmila. Representação social da mulher brasileira nas atividades físicodesportivas da segregação à democratização. Revista Movimento, Porto Alegre, v. 6, n. 13, p.5-18, dez, 2000. Disponível em: <http://seer.ufrgs.br/index.php/Movimento/article/ view/11777/6976>. Acesso em: 10 nov. 2018.

RAMOS, Adamilton Mendes; NEVES, Ricardo Lira Rezende. A iniciação esportiva e a especializaçáo precoce à luz da teoria da complexidade - notas introdutórias. Pensar a Prática, v. 11, n. 1, p. 1-8, mar, 2008. Disponível em: <https://www.revistas.ufg.br/fef/ article/view/1786/3339>. Acesso em: 02 out. 2018. 
SCAGLIA, Alcides José. Escolinha de futebol: uma questão pedagógica. Motriz, v. 2, n. 1, jun. 1996. Disponível em: <http://www.ludopedio.com.br/v2/content/uploads/270142_ V2n1_REL07.pdf>. Acesso em: 17 nov. 2018.

SAMPIERI, Roberto Hernández; COLLADO, Carlos Fernández; LUCIO, Maria del Pilar Baptista. Metodologia de pesquisa. 5. ed. Porto Alegre: Penso, 2013.

SAWITZKI, Rosalvo Luis. Esporte Escolar: aspectos pedagógicos e de formação humana. Motrivivência, Florianópolis, n. 31, p. 132-142, dez, 2008. Disponível em: <https:// periodicos.ufsc.br/index.php/motrivivencia/article/view/14093>. Acesso em: 15 nov. 2018.

SILVA, Junior V. P da Silva; SAMPAIO, Tânia M. Vieira. Os conteúdos das aulas de Educação Física no Ensino Fundamental: o que mostram os estudos? Revista Brasileira de Ciência e Movimento, v. 20, n. 2, p. 106-118, 2012. Disponível em: <https:// portalrevistas.ucb.br/index.php/RBCM/article/view/3007>. Acesso em: 10 nov. 2018.

STIGGER, Marco Paulo; LOVISOLO, Hugo. Esporte de rendimento e esporte na escola. Campinas: Autores Associados, 2009.

VAGO, Tarcísio Mauro. O "esporte na escola" e o "esporte da escola”: da negação radical para uma relação de tensão permanente. Revista Movimento, Porto Alegre, v. 3, n. 5 , p.4-17, ago. 1996. Disponível em: <http://seer.ufrgs.br/index.php/Movimento/article/ view/2228/936>. Acesso em: 28 abr. 2018. 